Divergence and Convergence of Automobile Fuel Economy Regulations 
Masahiko Iguchi

\section{Divergence and Convergence of Automobile Fuel Economy Regulations}

A Comparative Analysis of EU, Japan and the US

Springer 


\author{
Masahiko Iguchi \\ Department of International Relations \\ Faculty of Foreign Studies \\ Kyoto Sangyo University \\ Kyoto \\ Japan
}

ISBN 978-3-319-17499-0

ISBN 978-3-319-17500-3 (eBook)

DOI 10.1007/978-3-319-17500-3

Library of Congress Control Number: 2015935208

Springer Cham Heidelberg New York Dordrecht London

(C) Springer International Publishing Switzerland 2015

This work is subject to copyright. All rights are reserved by the Publisher, whether the whole or part of the material is concerned, specifically the rights of translation, reprinting, reuse of illustrations, recitation, broadcasting, reproduction on microfilms or in any other physical way, and transmission or information storage and retrieval, electronic adaptation, computer software, or by similar or dissimilar methodology now known or hereafter developed.

The use of general descriptive names, registered names, trademarks, service marks, etc. in this publication does not imply, even in the absence of a specific statement, that such names are exempt from the relevant protective laws and regulations and therefore free for general use.

The publisher, the authors and the editors are safe to assume that the advice and information in this book are believed to be true and accurate at the date of publication. Neither the publisher nor the authors or the editors give a warranty, express or implied, with respect to the material contained herein or for any errors or omissions that may have been made.

Printed on acid-free paper

Springer International Publishing AG Switzerland is part of Springer Science+Business Media (www.springer.com) 
For my parents, who have been giving me enduring supports 


\section{Preface}

This book was initially born out of the questions I formulated during my time as a Ph.D. student at Tokyo Institute of Technology throughout 2007-2012. As many scholars started to engage in the role of business actors in global environmental governance, discussions associating with the 'private environmental governance' became popular research foci. These discussions look at business efforts to 'green' themselves, and many address 'beyond the state' activities of business involvement in international environmental politics, i.e. how business communities establish codes of conduct or certification schemes to promote environmentally friendly products. Then I began to wonder why business sometimes chose to support stringent environmental regulation at home country and attempt to internationalize such regulatory standards, over international business networks to coordinate their efforts to green themselves? What is such business, and would it also happen in climate change issue? Which other non-state actors are crucial to promote such business supports for stringent environmental regulation at home country? Who gets, what and how, when such business supports are happening?

Year 2007 marked remarkable changes in fuel economy regulations for passenger cars in Europe, Japan and the US: while Europe and Japan progressively started to lead the regulations, the US for the first time in 20 years raised the corporate average fuel economy standards under the Energy Independence and Security Act. At the same time, the 'Bali roadmap' was adopted under the international climate negotiation taken place at the United Nations Framework Convention on Climate Change (UNFCCC) to set processes to finalizing a binding agreement at the 15 th Conference of the Parties (COP 15) in 2009. Although the COP15 resulted in a major disappointment, fuel economy regulations in Europe, Japan and the US continued to evolve and the regulatory standards for 2020-2025 started to converge throughout 2009-2012.

This book reveals the mechanism of the regulatory convergence of car fuel economy regulations between Europe, Japan and the US by drawing upon constructivist theory of International Relations and literatures that focus on business competition and environmental regulations. It offers new understandings on the topic of 'cars and carbon' by: 
- dealing with the emerging phenomenon of convergence of car fuel economy regulations,

- addressing the role of the business actor in pushing towards solution of climate change issue,

- proposing the new model of 'Agency with and beyond the states',

- providing rich case studies from Europe, Japan and the US.

To this end, this book is structured as follows.

Chapter 1, 'Introduction' first highlights the automobile industry and global climate change in order to provide an issue background.

Then, Chap. 2, 'Business Actors and Global Environmental Governance' shows where the proposed monograph stands in the discipline of political science, and demonstrates how this book would advance the study of business actors in global environmental governance.

Chapter 3, 'Construction of European Fuel Economy Regulations for Passenger Cars' looks at how Europe's climate policies for car $\mathrm{CO}_{2}$ emissions have been constructed. It asks, how and why has the European Union (EU) introduced these standards, even before Japan and the United States? What factors influenced these regulations, and which actors were instrumental in the decision-making process?

Chapter 4, 'Construction of Japanese Fuel Economy Regulations for Passenger Cars' argues that Japan adopted its stringent fuel economy regulation primarily because of industry competitiveness, which are motivated by stringent environmental regulations in export markets and encouraged by its tradition of 'co-regulation' and 'corporatism' to enhance the regulations. An earlier version of this chapter appeared in Masahiko Iguchi and Karl Hillman (2012) 'The Development of Fuel Economy Regulations for Passenger Cars in Japan'. In Nilsson et al. (eds.), Paving the Road to Sustainable Transport: Governance and innovation in lowcarbon vehicles. London: Routledge, pp. 57-69.

Chapter 5, 'Construction of the US Fuel Economy Regulations for Passenger Cars' addresses why, despite the US being the world's first country to introduce fuel economy regulations, has US fuel economy regulation been stagnant for more than 20 years? What political dynamics pushed the former Bush Administration, which had withdrawn from the Kyoto Protocol negotiation in 2001, to improve the fuel economy regulation standard? Why are the recent US fuel economy regulations now converging with the Japanese and European standards?

Chapter 6, 'Comparative Assessment' compares and contrasts fuel economy regulations that draw implications to the target for 2015 and beyond, by comparing and contrasting fuel economy regulations among three case studies.

Lastly, Chap. 7 'Conclusion' provides broader implications to theories, explores applicability of 'agency with and beyond the state' model to other sectors, and to climate governance as a whole, by answering research questions.

This book is intended for political scientists, especially scholars of global environmental politics. Experts on climate change politics may be the most interested readers, but as the study features new aspects of private environmental governance, I hope that it would serve as a source for the wider environmental 
study community. Also, I hope scholars of political economy who are interested in the role of the car industry, and researchers engaged in comparative research will find use for this book. The book can also serve for practitioners, including policy makers, informed activists, advisors, business community and related professionals. Above all, I would be extremely honoured if any student, who accidentally picked this book in the university library, would be motivated to study global environmental governance after reading this book.

Kyoto

Masahiko Iguchi

April 2015 


\section{Acknowledgments}

I would like to acknowledge that this book was only possible with the support of others. Although I cannot list all their name here, I would like to take the opportunity here to acknowledge some of those who have provided such support.

First of all, I would like to express the deepest gratitude to Prof. Norichika Kanie for his guidance, support, and continuous encouragement from the beginning of this research project at Tokyo Institute of Technology. He has not only taught me valuable insights into international environmental politics, but also provided me with many research opportunities and always tried to offer me a better research environment, for which I am deeply indebted.

I am also very grateful to Prof. Frank Biermann. He offered me to host a precious research opportunity at Institute for Environmental Studies (IVM), Vrije Universiteit Amsterdam from February to March 2010, gave me elaborate guidance for my dissertation, and inspired me through his grand perspectives on Earth System Governance.

I was lucky enough to work as a research fellow at the Faculty of Law, Keio University from October 2010 to March 2012, where I gained considerable advantages to improve my insights into political science. I would like to thank Prof. Toshiro Tanaka and Professor Yoshiaki Kobayashi for giving me a chance to work at Keio University. Special and big thanks go to my ex-colleagues, Taisuke Fujita and Shin Osawa for their friendships.

Knowing the state of UN negotiations was also inspiring experience that advanced the study of business in environmental politics. I would like to thank Mr. Mitsutoshi Hayakawa, an executive director of Citizens' Alliance for Saving the Atmosphere and the Earth (CASA) for enabling me to participate in several UNFCCC COP meetings with a wonderful team.

I have also had the privilege to discuss my ideas or co-author several publications with the following scholars: Masachika Suzuki, Harro van Asselt, Karl Hillman and Yuri Okubo.

As mentioned, an earlier version of Chap. 4 of this book is based on the previously published material from Routledge. I thank Routledge for permission to use the material. 
Special and big thanks go to Fritz Schmuhl, who has been more than helpful to materialize this book from the beginning.

Last but not least, extra special credit should be given to Azusa Omura, who has been supporting this research project from the beginning. She has not only been generous about cooperating, but also making every second of my life beautiful.

This work is dedicated to my parents, who have been giving me enduring support. Researching and writing this book has been long and challenging, but it was a wonderful journey indeed. 


\section{Contents}

1 Introduction. . . . . . . . . . . . . . . . . . . 1

1.1 Transformation of Business Towards Sustainability. . . . . . . 1

1.2 Automobile Industry and Global Climate Change........... 4

1.3 Research Puzzle and Hypothesis: Regulatory Convergence of Fuel Economy Regulation . . . . . . . . . . . . . . 7

1.4 Research Objectives: Revealing the Dynamics

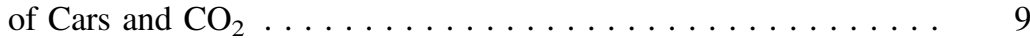

References.......................... 11

2 Business Actors in Global Environmental Governance . . . . . . . . 15

2.1 Business Actors in Global Environmental Governance:

A Classification of Business Involvement . . . . . . . . . 15

2.2 Existing Studies: Varieties of Capitalism

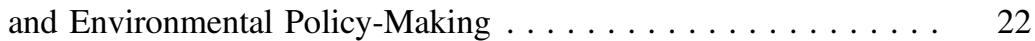

2.3 A Constructivist Perspective on Business Actors and Environmental Governance ................ 23

2.4 Automobile Industry in Global Climate Governance: 'Agency with and Beyond the States' . . . . . . . . . . . . 27

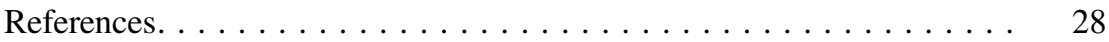

\section{Construction of European Fuel Economy Regulations}

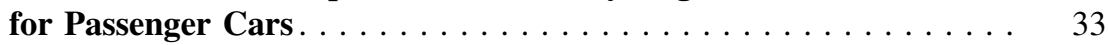

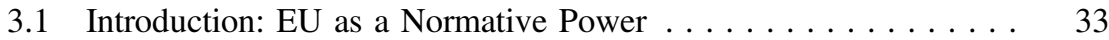

3.2 The Formative Years: The Early 1990s . . . . . . . . . . . . 36

3.3 The Appearance of the $120 \mathrm{~g} / \mathrm{km}$ Target: The Late $1990 \mathrm{~s} \ldots \ldots$. . 40

3.4 EU-Industry Voluntary Target: $1998-2006 \ldots \ldots \ldots \ldots \ldots \ldots . \ldots 2$

3.5 Critical Juncture: $2007 \ldots \ldots \ldots \ldots \ldots \ldots \ldots \ldots \ldots$ 
3.6 Target for 2015 and Beyond $\ldots \ldots \ldots \ldots \ldots \ldots \ldots \ldots \ldots$

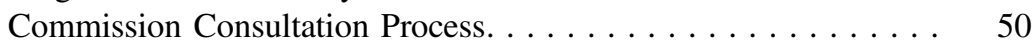

Discussion in the European Parliament . . . . . . . . . . 52

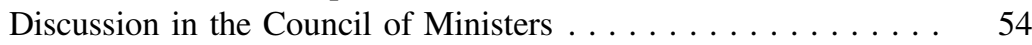

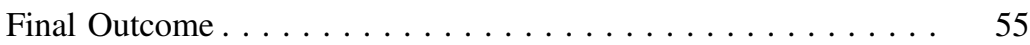

Target for Beyond 2015: Legalizing $95 \mathrm{~g} / \mathrm{km}$ Target. . . . . . . 59

3.7 Summary. . . . . . . . . . . . . . . . . . . . . . . . 59

References. . . . . . . . . . . . . . . . . . 64

4 Construction of Japanese Fuel Economy Regulations

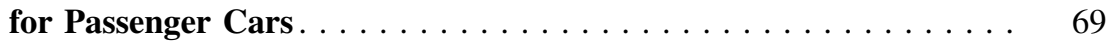

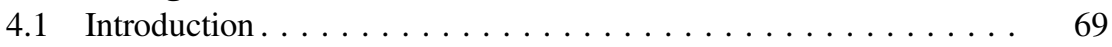

4.2 The Brief History of the Japanese Fuel Economy Regulation: Mid-1970s-Late 1990s . . . . . . . . . . . . 71

4.3 Impacts from the Regulation Abroad. . . . . . . . . . . . 72

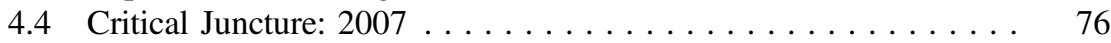

4.5 Target for Beyond $2015 \ldots \ldots \ldots \ldots \ldots \ldots \ldots \ldots \ldots \ldots$

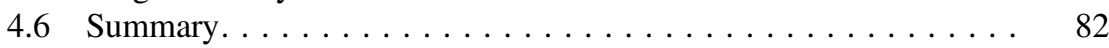

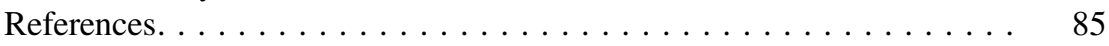

5 Construction of the US Fuel Economy Regulations

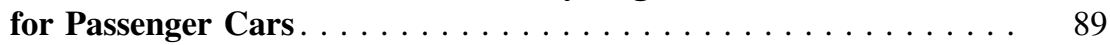

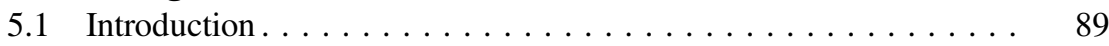

5.2 Formative Years: 1970s. . . . . . . . . . . . . . . . . . 91

5.3 Stagnation of the CAFE Standards: Mid-1980s. . . . . . . . . . 92

5.4 Critical Juncture: Massachusetts v. EPA (2007) . . . . . . . . . 98

5.5 The 2007 Energy Security and Independence Act. . . . . . . . . 100

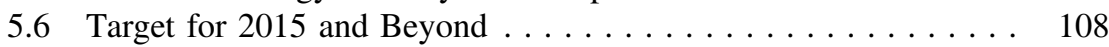

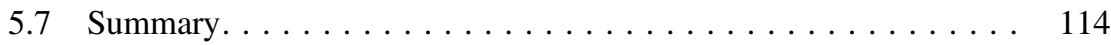

References.......................... 116

6 Comparative Assessment . . . . . . . . . . . . . . . . . . 119

6.1 Introduction . . . . . . . . . . . . . . . . . . . . . . 119

6.2 Motive of the Regulation. . . . . . . . . . . . . . . . . 120

6.3 Importance of Competitiveness Issue in Enhancing Regulations . . . . . . . . . . . . . . . 123

6.4 Decision-Making Process. . . . . . . . . . . . . . . . 125

6.5 The Critical Juncture and the Role of Non-state Actors . . . . . . 127

6.6 Implications for 2015 and Beyond . . . . . . . . . . . . 129

Implication to Regulatory Convergence for Heavy Duty Vehicles. . . . . . . . . . . . . . . . . 130

'Race to the Top', not 'Race to the Bottom' . . . . . . . . . 131 
References. .......................... 133

7 Conclusion. . . . . . . . . . . . . . . . . . . 135

7.1 Answering the Research Questions: Business

Competition and Environmental Policy-Makings. . . . . . . . . . 135

7.2 Theoretical Contributions. . . . . . . . . . . . . . . . . 137

Beyond the 'Variety of Capitalism'. . . . . . . . . . . . . 138

Constructing Constructivist Theory: The Regulatory

Convergence Is What Competition Make of It . . . . . . . . . . 139

7.3 Applicability of 'Agency Within and Beyond the State'

Model of Regulatory Convergence to Environmental Policies. . . . 142

7.4 Future Tasks . . . . . . . . . . . . . . . . . . . . . . . . 144

References. . . . . . . . . . . . . . . . . . . . . . 144

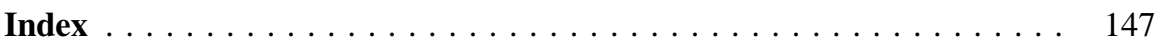




\section{Acronyms}

AAM American Automobile Manufacturers Association

ACEA European Automobile Manufacturers' Association

APP Asia-Pacific Partnership on Clean Development and Climate

BRICS Brazil, Russia, India, China and South Africa

CAFE Corporate Average Fuel Economy

CAN Climate Action Network

CCA US Clean Air Act

CFC Chlorofluorocarbon

CLEPA European Parts Manufactures' Association

CME Coordinated Market Economy

$\mathrm{CO}_{2} \quad$ Carbon Dioxide

COP Conference of Parties

DG The Directorate-General, European Commission

EPA US Environmental Protection Agency

EU European Union

FSC Forest Stewardship Council

FTA Free Trade Agreement

$\mathrm{g} / \mathrm{km} \quad$ Grams of $\mathrm{CO}_{2}$ per vehicle kilometre

GCC Global Climate Coalition

GHGs Greenhouse Gasses

GM General Motors

HEVs Hybrid Electric Vehicles

ICE Internal Combustion Engine

IR International Relations

JAMA Japan Automobile Manufacturers Association

KAMA Korean Automobile Manufactures' Association

$\mathrm{km} / \mathrm{L} \quad$ Kilometre per Litre

LEV California's low-emission vehicle regulation

LME Liberal Market Economy

METI Japanese Ministry of Economy, Trade and Industry

MLIT Japanese Ministry of Land, Infrastructure, Transport and Tourism 


$\begin{array}{ll}\text { MOE } & \text { Japanese Ministry of the Environment } \\ \text { mpg } & \text { Miles per gallon } \\ \text { MSC } & \text { Marine Stewardship Council } \\ \text { MVEG } & \text { Motor Vehicle Emission Group, European Community } \\ \text { NGOs } & \text { Non-Governmental Organizations } \\ \text { NSMD } & \text { Non-State Market Driven Governance } \\ \text { ODS } & \text { Ozone-Depleting Substances } \\ \text { PPPs } & \text { Public-Private Partnerships } \\ \text { R\&D } & \text { Research and Development } \\ \text { SUV } & \text { Sports Utility Vehicles } \\ \text { TPP } & \text { Trans-Pacific Partnership } \\ \text { UAW } & \text { Union of Automobile Workers, the US } \\ \text { UNFCCC } & \text { United Nations Framework Convention on Climate Change } \\ \text { US } & \text { The United States } \\ \text { VDA } & \text { German Car Manufactures' Association } \\ \text { VOC } & \text { Varieties of Capitalism } \\ \text { ZEVs } & \text { California's Zero-Emission Vehicles Regulation }\end{array}$

